\title{
Biofouling development and its effect on growth and reproduction of the farmed pearl oyster Pinctada margaritifera
}

\author{
Elise Lacoste ${ }^{a}$, Gilles Le Moullac ${ }^{b}$, Peva Levy $^{\mathrm{b}}$, Yannick Gueguen ${ }^{\mathrm{b}}$, Nabila Gaertner-Mazouni ${ }^{\mathrm{a},{ }^{*}}$ \\ a Université de la Polynésie Française, Ecosystèmes Insulaires Océaniens, UMR 241, BP6570-98702 Faa'a, \\ Polynésie française \\ ${ }^{\mathrm{b}}$ Ifremer, Ecosystèmes Insulaires Océaniens, UMR 241, BP 7004-98719 Taravao, Polynésie française \\ *: Corresponding author : Nabila Gaertner-Mazouni, email address : nabila.gaertner-mazouni@upf.pf
}

\begin{abstract}
:
In bivalve aquaculture, dominant fouling organisms are filter feeders which can compete for food with reared bivalves, sometimes causing mortality or reducing their growth rate. This study investigated the effect of biofouling on the farmed pearl oyster Pinctada margaritifera in two lagoons of French Polynesia. Survival, growth and reproduction of 2 year-old pearl oysters were monitored with regular sampling schedules, from the initial stage of colonization up to 20 months of biofouling accumulation. Control groups of pearl oysters were kept free of biofouling as is the current practice in pearl farms. After more than a year of monitoring, no significant difference was recorded in shell growth rate between pearl oysters reared with epibionts and the control group of pearl oysters, at both sites. Mean annual shell growth rate (height) was $30.5 \pm 9.2 \mathrm{~mm}$ in Tahiti and $24.8 \pm 7.7 \mathrm{~mm}$ in Mangareva. Neither the survival nor the reproduction indices were negatively affected by biofouling. In Mangareva, where biofouling development was quantified during 1 year, the rate of colonization appeared to be high during the first 3 months before slowing down. These results raise questions about the necessity of removing biofouling at this stage of pearl oyster production (i.e. before grafting).
\end{abstract}

\section{Highlights}

Effect of biofouling on growth and reproduction of pearl oysters (Pinctada margaritifera) was studied during 2 years. Results indicated no detrimental effect of biofouling on pearl oysters survival, growth and reproduction. The necessity of biofouling removal is questioned.

Keywords: Pearl oyster culture ; Pinctada margaritifera ; Biofouling ; Growth ; Reproduction

\section{Introduction}

Biofouling development is a key issue in bivalve aquaculture worldwide (Lacoste and Gaertner-Mazouni, 2014). The settlement and development of fouling organisms can have a range of negative impacts, including additional weight placed on infrastructure which may cause crop losses (Ramsay et al., 2008), as well as degradation of the shells of commercial species, thus decreasing their marketability (Handley and Bergquist, 1997, Nel et al., 1996 and Royer et al., 2006). Another main concern regarding biofouling is the potential competition for food induced by the settlement of filter-feeder epibionts (Claereboudt et al., 1994, Daigle and Herbinger, 2009 and Sievers et al., 2013). In addition, fouling by algae or by encrusting species on nets or trays can obstruct water flow, further reducing the amount of food reaching 
bivalves (de Sa et al., 2007). Such interferences can result in slow growth and in extreme cases to mortality of bivalves (Daigle \& Herbinger, 2009; de Sa et al., 2007; Lodeiros \& Himmelman, 1996), thus compromising aquaculture production.

In French Polynesia, aquaculture is based on the culture of pearl oysters (Pinctada margaritifera) for the production of black pearls. From the first rearing stages, high quantities of biofouling develop on pearl oysters' shells and on farm infrastructure (e.g. buoys, ropes, nets) (Mao Che, 1996). In other areas where pearl culture has been developed, biofouling has been demonstrated to impact pearl oysters, reducing growth rate or causing mortality of the farmed stock (Alagarswami \& Chellam, 1976; Kripa et al., 2012; Pit \& Southgate, 2003). Reproduction is also likely to be affected by biofouling development, because of its dependence on food supply (Acosta-Salmon \& Southgate, 2005). In particular, a nutritive stress in this protandric species could prevent the appearance of females for which energy demand is higher than for males (Chavez-Villalba et al., 2013).

In French Polynesia, because epibionts are suspected of being trophic competitors of cultured pearl oysters, they are regularly cleaned as a precaution measure. This process is labour intensive, requires equipment and may also cause additional stress to the pearl oysters. Unfortunately, the cost-effectiveness of such mitigation strategies is unknown, as no study has ascertained the efficiency of biofouling removal on pearl oysters (e.g. survival, growth) in this area. Hence, this study was conducted to help fill this gap. Our objective was to determine whether accumulation of biofouling can affect shell growth rate, flesh weight (as an indicator of physiological condition) and reproduction of $P$. margaritifera. This study also aimed to identify the temporal variations of biofouling in pearl farms with the hypothesis that different patterns of colonization occur with seasons.

\section{Materials and methods}

\subsection{Study sites and environment characterization}

Growth and reproduction of cultivated pearl oysters were studied at 2 sites in French Polynesia (Fig. 1). In Tahiti, the main island of French Polynesia, experiments took place in the south western part of the lagoon (Vairao). In the Gambier archipelago, our experiment was carried out in a pearl farm, located in the north western part of the main Island, Mangareva. In this area, pearl oyster farming is highly developed and the pearl farm used for the experiment had previously been identified as having a well-developed biofouling community. The 2 sites are high island lagoons, with depths of about 25-30 meters and intensive exchanges with the surrounding ocean waters.

Water temperature was continuously recorded at the 2 sites, near the cultivation areas. Chlorophyll-a (Chl-a) was sampled monthly in Vairao and during the two surveys in Mangareva by taking water samples at the long-line sites, using a Niskin bottle. Five hundred $\mathrm{ml}$ of water were filtered on Whatman GF/F $(0.7 \mu \mathrm{m})$ to measure Chl- $a$ contained in total phytoplankton, as a proxy of biomass. Filters were kept frozen until Chl-a was extracted with 
96\% ethanol during $6 \mathrm{~h}$, before concentration was determined using the fluorometric procedure described in Welschmeyer (1994).

\subsection{Pearl oysters culture and fouling control}

Specific sampling designs were set up on the 2 sites to meet the aims of the study. In Tahiti, the experimental population of pearl oysters was transferred from the Takapoto atoll (Tuamotu Archipelago) and reared in the lagoon at Vairao, by using the same cultivation technique as in pearl farms. Pearl oysters were "hung" on ropes (20 pearl oysters per rope, $\mathrm{n}=540$ ) on a long-line suspended at $7 \mathrm{~m}$ depth. At the beginning of the experiment, the initial population was divided into 2 groups. The first group was kept free of biofouling by regular cleaning (every 3 months from May 2012), as is the usual practice in pearl farms, using a pressure washer. The second group was never cleaned to assess the effectiveness of biofouling removal on growth performance and reproduction of pearl oysters over time. Pearl oysters in these 2 groups are referred to hereafter as clean pearl oysters (PO) and pearl oysters with biofouling communities (POBC). Pearl oysters were marked individually and growth and reproduction were followed monthly over 14 months of experiment (from March 2011 to May 2012). Each month, presence/absence of macrofouling groups was recorded on the collected pearl oysters (POBC) but biofouling biomass was not quantified. In Mangareva, our objective was to test the effect of biofouling development on pearl oyster growth rate and to identify more specifically the variations of biofouling over time. A higher time step was thus implemented and the experiment ran from November 2011 to July 2013. Pearl oysters of a same cohort were reared in a pearl farm, using "kangaroo nets" suspended at $7 \mathrm{~m}$ depth. The experimental population $(n=240)$ was partitioned into 5 groups, each group including 4 nets of 12 pearl oysters. All groups were immersed the same time (November 2011), but cleaned according to different schedules, to follow biofouling development at different periods of the year (Table 1). Group A was never cleaned (similar as POBC in Tahiti), so colonization was initiated in November 2011 and lasted until the end of experiment. Group E was cleaned every 3 months as control (corresponding to PO group of Tahiti), using a pressure washer. Three surveys were conducted in May 2012, November 2012 and July 2013 to monitor biofouling development and pearl oyster growth rate. In July 2013, all the experimental groups were accidentally cleaned by the farmer. We thus had to stop our experiment at this date and the pearl oysters were sent to the laboratory for final measurements. For each survey, one net of each treatment was collected and epibionts were removed before being weighed and identified.

For both experimental populations, the age of the pearl oysters at the beginning of monitoring was about 2 years old. Dead pearl oysters were counted and not used in growth calculations. 
Table 1. Colonization periods for each group over the entire experiment in Mangareva. The experiment ran between November 2011 and July 2013 with three surveys in May and November 2012 and July 2013 (frames). Cross marks indicates that a group was cleaned whereas the period in grey corresponds to the period of colonization. Final time of colonization (months) is indicated for each group and for the 3 surveys.

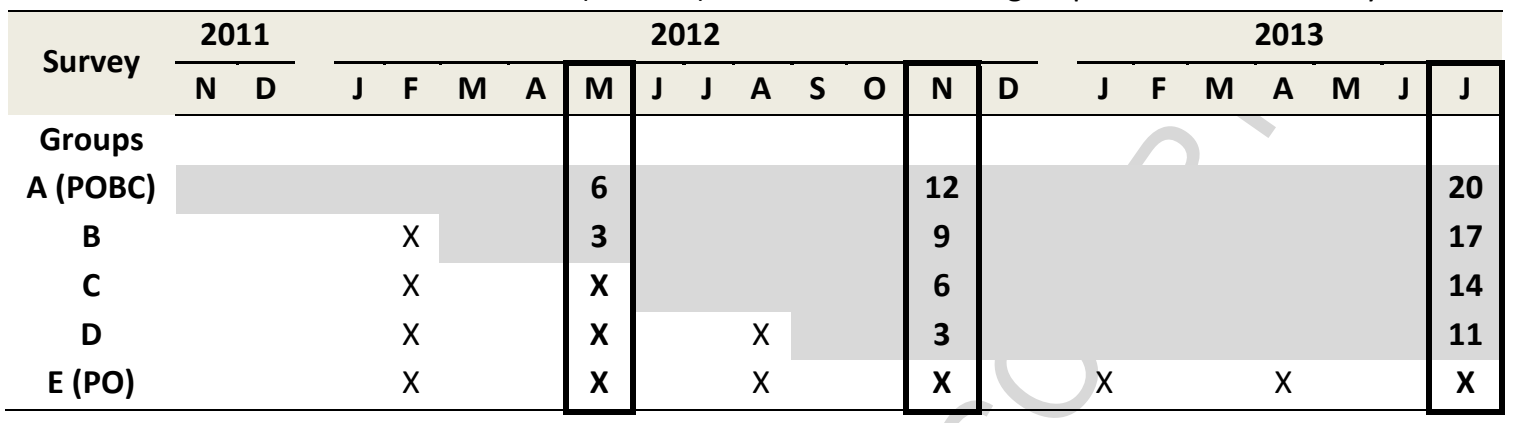

\subsection{Growth and reproduction monitoring}

\subsubsection{Growth measurement}

At the beginning of the experiments, all pearl oysters were measured for shell dimension with a caliper, to the nearest $0.1 \mathrm{~cm}$. Dorso-ventral measure (DVM) and Thickness were chosen as these parameters are considered as a good indicator of shell growth performance in pearl oysters and may be related to pearl growth (Wada \& Komaru, 1996; Sims, 1993; Bai et al., 2008). In Mangareva, all pearl oysters were also weighed (total wet weight: TWW) at the beginning of the experiments.

To document growth, 16 pearl oysters from each group were randomly collected in Tahiti $(n=32)$ at monthly intervals while one net of each group was collected in Mangareva $(n=60)$, for each survey (May 2012, November 2012 and July 2013). Pearl oysters were cleaned of epibionts and shell growth was measured externally. Pearl oysters were then dissected, for estimation of the total flesh wet weight (TFWW) after 5 min draining.

\subsubsection{Gonad development index and sex-ratio}

After growth measurement, visceral mass was separated from the rest of the flesh and put in $10 \%$ formalin for $48 \mathrm{~h}$ before being conserved in $70 \%$ ethanol. The visceral mass was then cut longitudinally and one half was digitized on a scanner to calculate the gonad development index (GDI) according to Le Moullac et al. (2013). The other part of the visceral mass was used for histological identification of reproductive stage and gender determination (see Fournier et al. 2012 for detail). Reproductive stages of gonad development were adapted from the description by Pouvreau et al. (2000) (Table 2). In Mangareva GDI and sexratio were only analyzed for groups A (POBC) and E (PO), in May and November 2012. 
Table 2. Histological stages of gametogenesis, adapted from Pouvreau (2000).

\begin{tabular}{lc}
\hline Stage description & Stage \\
\hline Indeterminate or inactive & 0 \\
Early gametogenesis & 1 \\
Intermediate (actively developing) & 2 \\
Mature & 3 \\
Spawned & $\mathrm{R}$ \\
\hline
\end{tabular}

\subsection{Data analysis}

Differences of growth and weight increment between the different groups of pearl oysters were assessed using ANCOVA (time as continuous variable in Tahiti) and two way ANOVA (time as discrete variable in Mangareva). Measurement errors (negative size increase) were excluded from the analysis. All data were graphically assessed for normality and homogeneity of residuals (Farraway, 2002). When one of the assumptions was violated, appropriate data transformations were performed. Data relating to the shell thickness and height (DVM) were square root transformed. Weights in Tahiti (TWW and TFWW) and TWW in Mangareva were log transformed $(\ln (x))$.

In the case of significant difference after an ANCOVA/ANOVA $(p<0.05)$, multiple comparison test was computed using Tukeys' "Honest Significant Difference" method (Tukey HSD), to explore the differences between groups and date.

Differences in sex ratio between clean and covered pearl oysters for the whole period were analyzed using $\chi^{2}$ test on contingency table while frequency of reproductive stages at each date was compared using Fishers' exact test. GDI were compared using ANOVA after an arcsinus square root transformation. Correlation between GDI and environmental variables were assessed using Spearmans' rank correlation coefficient as environmental data were not normally distributed.

At a given date, the effect of the duration of colonization on biofouling biomass in Mangareva was tested using Students' t-Test or ANOVA (when we had more than 2 groups, as in November). For an equal colonization duration, the effect of initial colonization time was tested using Students't-Test.

All analyses were performed using the R software (R Development Core Team, 2011).

\section{Results}

\subsection{Characterization of environmental conditions and biofouling}

\subsubsection{Environment}

Water temperature in Tahiti varied between $25.5^{\circ} \mathrm{C}$ in August 2011 and $28.5^{\circ} \mathrm{C}$ in March 2012 (Fig. 2a). Seasons were more pronounced in Mangareva with temperatures below $23^{\circ} \mathrm{C}$ in July/August and up to $29.5^{\circ} \mathrm{C}$ in March. For both sites, lower temperatures are recorded between June and November, corresponding to the austral winter under tropical latitude. Total Chl- $a$ concentration in Tahiti varied between $0.3 \mu \mathrm{g} \mathrm{l}^{-1}$ and $1 \mu \mathrm{g} . \mathrm{I}^{-1}$ except in January 
2012 when a peak was recorded $\left(1.8 \mu \mathrm{g} \mathrm{I} \mathrm{I}^{-1}\right)$ (Fig. 2b). The mean concentration of total Chl- $a$ for the entire period was $0.7 \mu \mathrm{g} \mathrm{I}^{-1}$. In Mangareva, Chl- $a$ concentration was about $0.8 \mu \mathrm{g} \mathrm{I}^{-1}$ during the 2 surveys (May and November 2012).

\subsubsection{Biofouling}

In Tahiti (Fig. 3a), ropes were characterized by an accumulation of organic material trapped between shells and along the ropes, especially from November 2012, after a rain event. The few macroscopic epibiont species recorded during the study were observed as soon as 3 months after immersion. Dominant classes were Bivalvia, Ascidiacea, Calcarea and Demospongia and Polychaeta, observed in at least $75 \%$ of the monthly sampling. In a few cases, non-attached organisms belonging to Malacostracea (50\%), Gastropoda (50\%) and Echinoidea (21\%) were found, especially after 10 months of colonization. Gastropoda and Malacostracea were observed with a frequency of $80 \%$ and $60 \%$ in 2012 against $44 \%$ and $30 \%$ in 2011 . This revealed the progressive creation of a complex multispecific compartment along the cultivated ropes, with the accumulation of organic matter.

In Mangareva, initial colonization was characterized by a rapid settlement of the colonial tunicate Didemnum sp. which spread and covered the valves of pearl oysters and the nets. Other dominant species observed belong to the class of Ascidiacea, Polychaeta, Bryozoa (several unidentified class) and Bivalvia. Anthozoa were also observed, with numerous anemones (Aiptasia sp.) and other associated non-sessile fauna such as crabs, amphipods, isopods (Fig. 3b). All the different epibiont groups were recorded at each observation, except a sponge (Demospongia) and a snail (Gastropoda) which were only recorded after 12 months of immersion of the net (group A, November 2012). The total weights of epibionts for the different groups and date in Mangareva are reported in Table 3. The major increase in fouling biomass occurred during the first stage of colonization (Table 3). For group A, biofouling accumulated at a rate of $130 \mathrm{~g} \mathrm{month}^{-1}$ during the first 6 months (November 2011 to May 2012) and $30 \mathrm{~g} \mathrm{month}^{-1}$ during the next 6 months (May 2012 to November 2012). For group B, weight increase was $300 \mathrm{~g} \mathrm{month}^{-1}$ during the first 3 months (February 2012 to May 2012) and slowed down to $142 \mathrm{~g} \mathrm{month}^{-1}$ during the next 6 months (May 2012 to November 2012). Season did not affect the rate of colonization since for groups $C$ and $D$ the monthly rate of colonization during the austral winter was as high as that observed in summer (groups A and B); $131 \mathrm{~g} \mathrm{month}^{-1}$ between May 2012 and November 2012 and $400 \mathrm{~g} \mathrm{month}^{-1}$ between August 2012 and November 2012 for groups C and D, respectively.

Statistical analyses indicate that the duration of colonization ( 3 to 12 months) had no effect on the weight of epibionts removed from the nets, either in May ( $\mathrm{t}=0.59, \mathrm{df}=3.9, p>0.5$ ) or in November $(\mathrm{F}=0.09, \mathrm{df}=1, p>0.5)$. The initiation of colonization (i.e. date of last cleaning) also had also no effect on the final fouling biomass both after 3 months $(\mathrm{t}=-1.66, \mathrm{df}=2.4, p>$ 0.1 ) or 6 months of immersion ( $\mathrm{t}=0.07, \mathrm{df}=3.9, p>0.5)$. 
Table 3. Total wet weight (mean $\pm s d$, expressed in gram) of epibionts collected for the different experimental groups in Mangareva.

\begin{tabular}{lcccccccc}
\hline & \multicolumn{3}{c}{ May 2012} & & \multicolumn{4}{c}{ November 2012 } \\
\cline { 2 - 3 } \cline { 5 - 8 } Group & $\mathrm{A}$ & $\mathrm{B}$ & & $\mathrm{A}$ & $\mathrm{B}$ & $\mathrm{C}$ & $\mathrm{D}$ \\
Colonization time (months) & 6 & 3 & & 12 & 9 & 6 & 3 \\
Epibionts weight (g) & & $804 \pm 300$ & $940 \pm 255$ & & $980 \pm 20$ & $1798 \pm 169$ & $786 \pm 316$ & $1197 \pm 80$ \\
\hline
\end{tabular}

\subsection{Effect of biofouling on pearl oyster growth rate}

Pearl oysters' mean dimensions for each site at the beginning of experiment are reported in Table 4. Over the sampling period in Tahiti $P$. margaritifera shell dimensions and weight increased regularly and significantly (Fig. 4 \& Table 5). A similar pattern of growth was observed for the $\mathrm{PO}$ and $\mathrm{POBC}$ groups, corresponding to the linear growth period during the first 3 years. From March 2011 to May 2012 (i.e. 423 days), mean individual size of $P$. margaritifera increased of $30.5 \pm 9.2 \mathrm{~mm}$ in height (DVM) and $6.2 \pm 1.5 \mathrm{~mm}$ in thickness. TWW reached $230.3 \pm 42.5 \mathrm{~g}$ and TFWW $29.4 \pm 6.6 \mathrm{~g}$ while the mean was $13 \pm 3.5 \mathrm{~g}$ in April 2011.

For the same duration in Mangareva (i.e. November 2011 to November 2012) mean DVM increased by $24.8 \pm 7.7 \mathrm{~mm}$, Thickness by $6.9 \pm 1.5 \mathrm{~mm}$ and TWW of $135.7 \pm 31.8 \mathrm{~g}$ (Fig. 5 ). FWW for pearl oysters after 12 months of growth was on average $31.2 \pm 5.4 \mathrm{~g}$. Between November 2012 and July 2013, growth was no longer significant for any of the groups and for all variables measured (Tukey HSD).

ANCOVA indicated a significant effect of treatment on DVM in Tahiti, with a higher mean increase for PO group than for POBC group, but no significant difference was detected between the 2 groups at the same date (Tukey HSD) (Table 5). Treatment effect was significant on Thickness and TFWW in Mangareva (Tables 6). A post-hoc comparison indicated a difference between group $A$ and groups $B$ and $C$ for Thickness $(A>B, C)$ and $a$ difference between $C$ and groups $A$ and $B$ for TFWW in July 2013 ( $C>A, B$ ). The interaction Time*Treatment affected TFWW in Tahiti and TWW in Mangareva. For these two variables, Tukey HSD indicated no differences between groups for the same date.

During the whole experiment at the 2 sites, oyster mortality was low $(<5 \%)$. In Tahiti and Mangareva respectively, we recorded 3 and 2 dead pearl oysters for POBC group and 8 and 5 dead pearl oysters in $\mathrm{PO}$ group.

Table 4. Initial measurement (mean $\pm \mathrm{sd}$ ) of shell dimensions (height: DVM; Thickness) and weight (total wet weight: TWW) for the whole population in Tahiti $(n=540)$ and Mangareva $(n=240)$. TWW of pearl oysters in Tahiti is from a subsample of the initial population $(n=20)$.

\begin{tabular}{|c|c|c|c|}
\hline & $\operatorname{DVM}(\mathrm{mm})$ & Thickness (mm) & TWW (g) \\
\hline Tahiti & $80.6 \pm 9.2$ & $24.2 \pm 3$ & $85.5 \pm 10$ \\
\hline Mangareva & $91.9 \pm 6.2$ & $26.1 \pm 1.9$ & $103.6 \pm 18$ \\
\hline
\end{tabular}


Table 5. ANCOVAs testing the effect of date, treatment and their interaction on pearl oysters' size increase (height: DVM ; Thickness) and weight (total wet weight: TWW; total flesh wet weight: TFWW) in Tahiti. Significant values $(p<0.05)$ are indicated in bold.

\begin{tabular}{|c|c|c|c|c|c|c|c|c|c|c|c|c|c|c|c|}
\hline \multirow{2}{*}{$\begin{array}{l}\text { Source of } \\
\text { variation }\end{array}$} & \multicolumn{4}{|c|}{ DVM } & \multicolumn{4}{|c|}{ Thickness } & \multirow[b]{2}{*}{ Df } & \multicolumn{3}{|c|}{ TFWW } & \multicolumn{3}{|c|}{ TWW } \\
\hline & Df & MS & $\mathbf{F}$ & p-value & Df & MS & $\mathbf{F}$ & p-value & & MS & $\mathbf{F}$ & p-value & MS & $\mathbf{F}$ & p-value \\
\hline Time & 1 & 500.87 & 663.81 & $<0.001$ & 1 & 80.55 & 366.62 & $<0.001$ & & 34.28 & 459.49 & $<0.001$ & 25.82 & 433.16 & $<0.001$ \\
\hline Treatment & 1 & 4.51 & 5.98 & 0.015 & 1 & 0.10 & 0.48 & 0.495 & & 0.11 & 1.46 & 0.228 & 0.01 & 0.18 & 0.674 \\
\hline Time*Treatment & 1 & 0.42 & 0.55 & 0.457 & 1 & 0.06 & 0.28 & 0.594 & & 0.79 & 10.59 & $<0.005$ & 0.01 & 0.09 & 0.766 \\
\hline Residuals & 386 & 0.75 & & & 361 & 0.22 & & & & 0.07 & & & 0.06 & & \\
\hline
\end{tabular}

Table 6. Two-way ANOVAs testing the effect of date, treatment and their interaction, on pearl oysters' size increase (height: DVM; Thickness) and weight (total wet weight: TWW; total flesh wet weight TFWW) in Mangareva. Significant values $(p<0.05)$ are indicated in bold.

\begin{tabular}{|c|c|c|c|c|c|c|c|c|c|c|c|c|c|c|c|}
\hline \multirow{2}{*}{$\begin{array}{l}\text { Source of } \\
\text { variation }\end{array}$} & \multirow[b]{2}{*}{ Df } & \multicolumn{3}{|c|}{ DVM } & \multicolumn{3}{|c|}{ Thickness } & \multicolumn{4}{|c|}{ TFWW } & \multicolumn{4}{|c|}{ TWW } \\
\hline & & MS & $\mathbf{F}$ & p-value & MS & $\mathbf{F}$ & p-value & Df & MS & $\mathbf{F}$ & p-value & Df & MS & $\mathbf{F}$ & p-value \\
\hline Time & 2 & 211.45 & 330.28 & $<0.001$ & 25.66 & 334.89 & $<0.001$ & 2 & 1080.07 & 38.76 & $<0.001$ & 2 & 16.83 & 320.13 & $<0.001$ \\
\hline Treatment & 4 & 0.89 & 1.405 & 0.236 & 0.32 & 4.18 & $<0.005$ & 4 & 238.93 & 8.57 & $<0.001$ & 4 & 0.12 & 2.26 & 0.065 \\
\hline Time*Treatment & 8 & 1.05 & 1.64 & 0.117 & 4 & 0.53 & 0.778 & 6 & 44.85 & 1.61 & 0.148 & 7 & 0.17 & 3.18 & $<0.005$ \\
\hline Residuals & 156 & 0.64 & & & 0.08 & & & 147 & 27.87 & & & 145 & 0.05 & & \\
\hline
\end{tabular}




\subsection{Effect of biofouling on pearl oyster reproduction}

Treatment, date and the interaction of the two factors had a significant effect on GDI (Table 8), but after a multiple comparisons test, no differences were detected between the two groups at the same date (Tukey HSD). GDI values ranged between 0.05 in June/July 2011 and 0.25 between January and March 2012 (Fig. 6).

Study of the maturity stages revealed a strong asynchrony between individuals in the 2 groups (PO and POBC) (Fig. 7). Frequency of maturity stages were significantly different between the 2 groups only at the end of monitoring, in March and May 2012 (Fishers' test, $p<0.001$ ). PO group had 13 pearl oysters in (R) stages in March 2012 (0 for POCB group), whereas in May 2012 POBC group had 9 pearl oysters in (R) whereas pearl oysters of PO group were all mature (stages 2 and 3 ). Except for this difference, the 2 groups showed the same trends in reproduction.

Coupling the analysis of GDI and maturity stages, 3 periods could be identified. During the first period following the transfer of pearl oysters, GDI remained under the annual mean value for the 2 groups. During this period, a majority of individuals were inactive $(0)$ and in regression ( $R$ ) stages, so it corresponds to a resting period, possibly post-spawning (Fig. 7). Then, GDI increased continuously for the 2 groups between September and January until gained its maximum values in January 2012 for POBC and in March 2012 for PO. This corresponds to a maturation period, as indicated by the majority of stages 2 and 3 observed with the histological analysis (Fig. 7). From January, GDI values remained above the average value but decreased again for the two groups until the end of monitoring, when high frequency of regression stages $(R)$ was recorded ( $70 \%$ to $80 \%$ individuals of each group). This could correspond to a spawning event for a major part of the population, with a slight time lag between $\mathrm{PO}$ and $\mathrm{POBC}$ groups.

Using correlation test between GDI and environmental data in Tahiti, we found positive and significant relations with both $\mathrm{Chl}-a(r h o=0.61, p<0.05)$ and temperature $(r h o=0.89, p<$ 0.001). For the estimation of these correlations, individuals of $\mathrm{PO}$ and $\mathrm{POBC}$ groups were pooled as no difference was detected for the same date. In Mangareva, treatment had no effect on GDI but values were higher in November $(0.18 \pm 0.08)$ than in May $(0.10 \pm 0.05)$ (Table 7).

Males outnumbered females at both sites. A total of 14 and 6 females were recorded in Tahiti and Mangareva respectively. In Tahiti, more females were recorded on $\mathrm{POBC}$ group $(7 \%)$ than on PO group (3\%) for the whole period, but the difference was not significant $\left(\chi^{2}\right.$ $=2.19, d f=1, p=0.139$ ). Females were observed from the first sampling date in the 2 groups. 
Table 7. Two-way ANOVAs testing the effect of time and treatment on gonad development index (GDI) in Tahiti and Mangareva. Significant values $(p<0.05)$ are indicated in bold.

\begin{tabular}{|c|c|c|c|c|c|c|c|c|}
\hline \multirow{2}{*}{$\begin{array}{l}\text { Source of } \\
\text { variation }\end{array}$} & \multicolumn{4}{|c|}{ Tahiti } & \multicolumn{4}{|c|}{ Mangareva } \\
\hline & Df & MS & $\mathbf{F}$ & p-value & Df & MS & $\mathbf{F}$ & p-value \\
\hline Time & 13 & 0.43 & 59.24 & $<0.001$ & 1 & 0.29 & 28.81 & $<0.001$ \\
\hline Treatment & 1 & 0.03 & 4.45 & 0.035 & 1 & $<0.01$ & 0.04 & 0.947 \\
\hline Time*Treatment & 13 & 0.02 & 2.38 & $<0.001$ & 1 & $<0.01$ & 0.09 & 0.755 \\
\hline Residuals & 401 & 0.01 & & & 37 & 0.01 & $<0.01$ & \\
\hline
\end{tabular}

\section{Discussion}

\subsection{Development of biofouling communities}

In Mangareva, from 3 to 12 months of immersion, epibionts biomass reached between $800 \mathrm{~g}$ and $1.8 \mathrm{~kg}$ wet weight on a reared net of 12 pearl oysters that may represent up to $75 \%$ of the total weight of a reared net (net + pearl oysters + epibionts). The various cleaning schedules did not show any influence of regular cleaning on the accumulation of biofouling since the same biomass of epibionts was recorded for nets cleaned 1, 2, 3 times and those never cleaned over the course of experiment. Furthermore, no clear seasonal trend of colonization was observed for either of the two study sites. When pearl oysters were left uncleaned for more than 3 months, it seems that the rate of biofouling development could decrease. This slowing down of colonization with time was also observed by other authors (Leca, 1992; Taylor et al., 1997), who argued that supplementary colonization may be inhibited by animals already settled on structures. This finding supports the hypothesis of a potential "stabilization" of the epibiont community with time (Cifuentes et al. 2010, Greene \& Schoener 1982). Unfortunately, our data cannot confirm this hypothesis because the biofouling (accumulated during 20 months) was accidentally cleaned by the pearl farmer in July 2013. Further experiments are thus needed to confirm this result.

\subsection{Biofouling effects on pearl oyster growth rate}

The present study documented, a shell growth rate that was equivalent to that observed by Pouvreau \& Prasil (2001), who found shell height increased by $29.6 \mathrm{~mm}$ in Tahiti and 24.8 $\mathrm{mm}$ in Mangareva for pearl oysters of the same size class (2 year-old) over one year of observations. Growth was continuous over the year, without apparent influence of phytoplankton biomass ( $\mathrm{Chl}-a$ ) or of temperature, whose values during experiments were in the optimum range for this species (Yukihira et al. 2000).

Biofouling here has not been shown to adversely affect the growth or survival of pearl oysters. Growth of clean (PO) and covered groups (POBC) for both sites and all measured variables were never significantly different at a given date. Biofouling removal thus did not improve the growth rate of pearl oysters in this study, even compared with pearl oysters uncleaned during 20 months. Such results differ from other studies on pearl oysters, whose authors found no effect of biofouling on survival but a negative effect on pearl oyster growth 
rate (Pit \& Southgate, 2003; Taylor et al., 1997). Taylor et al. (1997) reported that Pinctada maxima cleaned every 2-4 weeks had a better growth rate than pearl oysters cleaned every 8 or 16 weeks. Others studies also revealed a negative effect of biofouling on survival of pearl oysters (Alagarswami \& Chellam, 1976; Kripa et al., 2012). The experimental set-up of these studies differed however from that of the present research; pearl oysters were reared in lantern nets or in plastic trays and epibionts were observed to overgrow the mesh, which may have, according to the authors, "prevented sufficient water flow to reach pearl oysters, thereby resulting in a lower food supply". Furthermore, pearl oysters used in their experiments were mostly juveniles, so supplementary weight on their valves may have prevented their opening for filtration, more than for the adult pearl oysters used in this study. A difference of biofouling impact according to the size class of bivalves has also been described for mussels (Fletcher et al., 2013; Sievers et al., 2013).

The absence of a measurable effect on growth and mortality reported here suggests that epibionts do not adversely affect the nature or quantity of food available to the pearl oysters under the conditions studied. Even if epibionts are empirically considered as trophic competitors for pearl oysters, no evidence of competition has been experimentally proven and the results of the present study show that even if trophic competition occurs, it is limited, as it does not alter pearl oyster growth within our study region. Such findings are in accordance with others studies reporting a neutral effect of biofouling on cultured bivalves for mussels (Laihonen \& Furman, 1986; Fletcher et al., 2013), oysters (Mallet et al., 2009; Royer et al., 2006) and pearl oysters (Lodeiros et al., 2002).

\subsection{Biofouling effects on pearl oyster reproduction}

In this study, P. margaritifera exhibited continuous reproductive activity over the year, with an overall asynchrony between individuals among groups. This is commonly reported for Pinctada margaritifera (Acosta-Salmon \& Southgate, 2005; Fournier et al., 2012; Le Moullac et al., 2012) and other Pinctada spp. (Garcia-Dominguez et al., 1996; O'Connor, 2002). Recorded values of the gonad development index (GDI) are consistent with those reported by Fournier et al. (2012) for P. margaritifera in the Ahe lagoon (Tuamotu atoll), where GDI varied between 0.08 and 0.29 . The observed variations of GDI matched well with histological observations. Despite the fact that maturity stages and GDI were generally asynchronous within populations, probable synchronized gamete release events (up to $80 \%$ of individuals) were observed between January and May 2012. This active period corresponded to a simultaneous increase of temperature and Chl- $a$ concentration in our study locations. In Mangareva, the higher value of GDI also corresponded with an increase in Chl- $a$ concentration recorded. These results confirm that temperature and trophic resource availability are key factors influencing the reproductive cycle of Pinctada spp. (Urban 2000; Fournier et al., 2012).

Biofouling has been suggested to be a potential factor affecting reproduction of bivalves because it would induce nutritive stress (Acosta-Salmon \& Southgate, 2005; Sievers et al., 2013), and thus the energetic trade-off could be unbalanced in favor of resistance to stress 
instead of reproduction (Petes et al., 2008). In this study, biofouling did not appear to influence the reproductive cycle of pearl oysters. For a given site, the filling index (i.e. GDI) reached the same values for $\mathrm{PO}$ and $\mathrm{POBC}$ groups, indicating that gonad storage is apparently not disrupted by biofouling. The hypothesis of nutritive stress induced by epibionts which may affect reproduction is thus not confirmed here.

Although no statistical difference was recorded for sex-ratio, a higher proportion of females was obtained in the POBC group for the whole year in Tahiti. From this result, we propose the hypothesis that instead of being stressed by biofouling development, pearl oysters are stressed by repeated handling for cleaning. This important finding needs to be confirmed since achieving good culture conditions to produce a large proportion of females in the context of the hatchery is crucial for French Polynesia (Chavez-Villalba et al., 2011; Le Moullac et al., 2013). Further experiments will be thus implemented to better understand the parameters influencing the reproductive cycle, including biofouling and husbandry methods.

\subsection{Implications for pearl oyster culture industry}

Very little is known about biofouling development and its impact on pearl oyster culture in French Polynesia. However, the usual practice involves regularly cleaning pearl oysters (every 3-6 months), to prevent any detrimental effect on production. Several studies reporting results of the impact of biofouling on pearl oyster growth, advocated that fouling should be regularly removed to maximize growth and reduce the risk of shell deformities. Taylor et al. (1997) suggested monthly removal while Kripa et al. (2012) recommended monthly or fortnightly removal depending on the season. Here, we showed that despite high biofouling development, cleaning appears unnecessary as it did not improve the growth rate of pearl oysters during the period of experimentation. Furthermore, some cleaning treatment has been described as negatively affecting pearl oysters. Too frequent cleaning may damage pearl oysters' shells which may progressively degrade the periostracum, leading to facilitation of recolonization over time (Mao Che, 1996; Pit \& Southgate, 2003; Guenther et al., 2006). Some cleaning methods are also stressful for pearl oysters (Kuchel et al., 2012), suggesting that this could be a problem, as suspected here for reproduction. Potential negative effects of biofouling removal, with the absence of measurable negative effect on pearl oysters, is therefore in favor of avoiding cleaning treatment during this stage of cultivation (i.e. before grafting), so time and money invested in cleaning could be saved. Similar experiments should however be conducted on more stages of cultivation and in other farming areas in French Polynesia, since biofouling is very specific to each geographical area. Moreover, further experiments are needed to confirm the absence of negative impact of biofouling on the final product: the pearl. We showed here that energy requirements for growth and reproduction are met despite the presence of epibionts. But after the graft, pearl oysters need additional energy for pearl formation. It is thus necessary to ensure that epibiont presence does not impair this stage of culture in order to obtain good quality 
pearls. The next step of this work will in fact be to study the shell biomineralization processes under conditions of biofouling.

\section{Acknowledgements}

This study received financial support from the Agence Nationale de la Recherche within the framework of the program AGROBIOSPHERE (ANR-11-AGRO-006). Financial support was also received from the French Government and the government of French Polynesia (project Biodiperl 2011-2013). E. Lacoste was supported by a PhD fellowship from the Ministère de I'Enseignement Supérieur et de la Recherche at the University of French Polynesia. We express our gratitude to the Ifremer staff for their efficient help during sample collection. We are also grateful to D. Devaux for his interest in our research and to all the technical staff present at his farm, for their effective and kind assistance in Mangareva. We would like to address special thanks to $\mathrm{S}$. Nakasai for all his assistance and collaboration for field measurements. 


\section{Figure Caption}

Fig. 1. Location of the two study sites in French Polynesia. Mangareva is located $1700 \mathrm{~km}$ south east of Tahiti, in the Gambier archipelago.

Fig.2. (a) Weekly mean of water temperature at the two study sites. Dashed line: Tahiti from March 2011 to May 2012; solid line: Mangareva from November 2011 to July 2013. (b) Monthly values of chlorophyll-a concentration $\left(\mu \mathrm{gl}^{-1}\right.$ ) recorded in Tahiti during the course of the experiment. Values are mean \pm standard deviation.

Fig.3. Clean (PO) and colonized (POBC) pearl oysters in Tahiti (a) and Mangareva (b) after one year of experiment.

Fig. 4. P. margaritifera growth in Tahiti over the 14 months of monitoring. Panels indicate: size increase ( $\mathrm{mm}$ ) for shell height (a, DVM) and shell Thickness ( $b$, Thick); and measured total wet weight (c, TWW) and total flesh wet weight ( $d, T F W W$ ). Values are mean \pm SE $(n=16)$. Solid line is for colonized pearl oysters (POBC) and blue dashed line for cleaned pearl oysters (PO).

Fig. 5. Temporal progression of $P$. margaritifera growth in Mangareva. Size increase for shell height (a, DVM) and shell Thickness (b), weight increase for total wet weight (c, TWW) and measured flesh wet weight ( $d$, TFWW), for the five groups and the three sampling dates. Error bars indicates standard error $(n=12)$. Duration of colonization for each group and each date is reported in Table 2.

Fig. 6. Gonad development index (GDI) for pearl oysters reared in Tahiti: colonized pearl oysters $(a, P O B C)$ and cleaned pearl oysters $(b, P O)$. Values are mean $\pm S E(n=16)$ of monthly subsample over the 14 months of monitoring. Horizontal line represents the mean value of GDI for the entire period of monitoring and colored areas above/below the continuous line indicate periods with values higher/lower than the mean.

Fig. 7. Frequency of maturity stages observed by histology during the experiment in Tahiti. (a) Pearl oysters colonized by biofouling (POBC) and (b) clean pearl oysters (PO). 


\section{References}

Acosta-Salmon, H., Southgate, P., 2005. Histological changes in the gonad of the blacklip pearl oyster (Pinctada margaritifera Linnaeus, 1758) during the reproductive season in north Queensland, Australia. Molluscan Res. 25(2), 71-74.

Alagarswami, K., Chellam, A., 1976. On fouling and boring organisms and mortality of pearl oysters in the farm at Veppalodai, Gulf of Mannar. Indian J. Fish. 23(1\&2), 10-22.

Bai, Z., Li, J., Wang, G., 2008. Relationship between pearl production, growth traits and the inserted position of mantle piece in triangle mussel (Hyriopsis cumingii). J Fish Sci China. 15(3), 493-499.

Chavez-Villalba, J., Soyez, C., Aurentz, H., Le Moullac, G., 2013. Physiological responses of female and male black-lip pearl oysters (Pinctada margaritifera) to different temperatures and concentrations of food. Aquat. living Resour. 271, 263-271.

Chávez-Villalba, J., Soyez, C., Huvet, A., Gueguen, Y., Lo, C., Le Moullac, G., 2011. Determination of Gender in the Pearl Oyster Pinctada margaritifera. J. Shellfish Res. 30, 231-240.

Cifuentes, M., Krueger, I., Dumont, C.P., Lenz, M., Thiel, M., 2010. Does primary colonization or community structure determine the succession of fouling communities? J. Exp. Mar. Bio. Ecol. 395, 10-20.

Claereboudt, M.R., Bureau, D., Côté, J., Himmelman, J.H., 1994. Fouling development and its effect on the growth of juvenile giant scallops (Placopecten magellanicus) in suspended culture. Aquaculture 121, 327-342.

Daigle, R., Herbinger, C., 2009. Ecological interactions between the vase tunicate (Ciona intestinalis) and the farmed blue mussel (Mytilus edulis) in Nova Scotia, Canada. Aquat. Invasions 4, 177187.

De Sá, F., Nalesso, R., Paresque, K., 2007. Fouling organisms on Perna perna mussels: is it worth removing them? Brazilian J. Oceanogr. 55(2), 155-161.

Faraway, J., 2002. Practical Regression and ANOVA using R.

Fletcher, L., Forrest, B., Bell, J., 2013. Impacts of the invasive ascidian Didemnum vexillum on greenlipped mussel Perna canaliculus aquaculture in New Zealand. Aquac. Environ. Interact. 4, 17-30.

Fournier, J., Levesque, E., Pouvreau, S., Le Pennec, M., Le Moullac, G. 2012. Influence of plankton concentration on gametogenesis and spawning of the black lip pearl oyster Pinctada margaritifera in Ahe atoll lagoon (Tuamotu archipelago, French polynesia). Mar. Pollut. Bull. 65, 463-70.

Garcia-Dominguez, F., Ceballos-Vázquez, B., Tripp-Quezada, A., 1996. Spawning cycle of the pearl oyster, Pinctada mazatlantica (Hanley, 1856),(Pteriidae) at Isla Espiritu Santo, Baja California Sur, Mexico. J. Shellfish Res. 15, 297-303.

Greene, C.H., Schoener, A., 1982. Succession on marine hard substrata: A fixed lottery. Oecologia 55, 289-297. 
Guenther, J., Southgate, P., Denys, R., 2006. The effect of age and shell size on accumulation of fouling organisms on the Akoya pearl oyster Pinctada fucata (Gould). Aquaculture 253, $366-$ 373.

Handley, S., Bergquist, P., 1997. Spionid polychaete infestations of intertidal pacific oysters Crassostrea gigas (Thunberg), Mahurangi Harbour, northern New Zealand. Aquaculture 153, 191-205.

Kripa, V., Mohamed, K.S.,Velayudhan, T.S., 2012. Seasonal Fouling Stress on the Farmed Pearl Oyster, Pinctada fucata, from Southeastern Arabian Sea. J. World Aquac. Soc. 43(4), 514-525.

Kuchel, R.P., McCarthy, A., Raftos, D. A., 2012. Phenoloxidase activity as an indicator of stress in the silver-lip pearl oyster, Pinctada maxima. Aquaculture. 364-365, 224-229.

Lacoste, E., Gaertner-Mazouni, N., 2014. Biofouling impact on production and ecosystem functioning: a review for bivalve aquaculture. In press, DOI: 10.1111/raq.12063

Laihonen, P., Furman, E., 1986. The site of settlement indicates commensalism between blue mussel and its epibiont. Oecologia. 71, 38-40.

Le Moullac, G., Tiapari, J., Teissier, H., Martinez, E., Cochard, J-C., 2012. Growth and gonad development of the tropical black-lip pearl oyster, Pinctada margaritifera (L.), in the Gambier archipelago (French Polynesia). Aquac. Int. 20, 1-11.

Le Moullac, G., Soyez, C., Sham-Koua, M., Levy, P., Moriceau, J., Vonau, V., Maihota, M., Cochard, JC., 2013. Feeding the pearl oyster Pinctada margaritifera during reproductive Conditioning. Aquac. Res. 44, 404-411.

Leca, L., 1992. Etude des épibiontes associéss à l'huitre perlière Pinctada margaritifera dans deux atolls de Polynésie Française. PhD Thesis. Université de Polynésie Française.

Lodeiros, C., Himmelman, J., 1996. Influence of fouling on the growth and survival of the tropical scallop, Euvola (Pecten) ziczac (L. 1758) in suspended culture. Aquac. Res. 27(10), 749-756.

Lodeiros, C., Pico, D., Prieto, A., Narváez, N., Guerra, A., 2002. Growth and survival of the pearl oyster Pinctada imbricata (Röding 1758) in supended and bottom culture in the Golfo de Cariaco, Venezuela. Aquac. Int. 10, 327-338.

Mallet, A.L., Carver, C.E., Hardy, M., 2009. The effect of floating bag management strategies on biofouling, oyster growth and biodeposition levels. Aquaculture 287, 315-323.

Mao Che, L., Campion-Alsumard, T., Boury-Esnault, N., Payri, C., Golubic, S., Bézac, C., 1996. Biodegradation of shells of the black pearl oyster, Pinctada margaritifera var. cumingii, by microborers and sponges of French Polynesia. Mar. Biol. 126, 509-519.

Nel, R., Coetzee, P.S., Van Niekerk, G., 1996. The evaluation of two treatments to reduce mud worm (Polydora hoplura Claparkde) infestation in commercially reared oysters (Crassostrea gigas Thunberg ). Aquaculture 141, 31-39.

O'connor, W., 2002. Latitudinal variation in reproductive behavior in the pearl oyster, Pinctada albina sugillata. Aquaculture.209(1), 333-345. 
Petes, L., Menge, B., Harris, A., 2008. Intertidal mussels exhibit energetic trade-offs between reproduction and stress resistance. Ecol. Monogr. 78(3), 387-402.

Pit, J.H., Southgate, P.C., 2003. Fouling and predation; how do they affect growth and survival of the blacklip pearl oyster, Pinctada margaritifera, during nursery culture? Aquac. Int. 11, 545-555.

Pouvreau, S., Prasil, V., 2001. Growth of the black-lip pearl oyster, Pinctada margaritifera, at nine culture sites of French Polynesia : synthesis of several sampling designs conducted between 1994 and 1999. Aquat. Living Resour. 14, 155-163.

Pouvreau, S., Gangnery, Tiapari, J., A., Lagarde, F., Garnier, Bodoy, A., 2000. Gametogenic cycle and reproductive effort of the tropical blacklip pearl oyster, Pinctada margaritifera (Bivalvia: Pteriidae), cultivated in Takapoto atoll (French Polynesia). Aquat. Living Resour. 13, 37-48.

Ramsay, A., Davidson, J., Landry, T., Arsenault, G., 2008. Process of invasiveness among exotic tunicates in Prince Edward Island, Canada. Biol. Invasions 10, 1311-1316.

Royer, J., Ropert, M., Mathieu, M., Costil, K., 2006. Presence of spionid worms and other epibionts in Pacific oysters (Crassostrea gigas) cultured in Normandy, France. Aquaculture 253, 461-474.

Sievers, M., Fitridge, I., Dempster, T., Keough, M.J., 2013. Biofouling leads to reduced shell growth and flesh weight in the cultured mussel Mytilus galloprovincialis. Biofouling 29, 97-107.

Sims, N., 1993. Size, age and growth of the black-lip pearl oyster, Pinctada margaritifera(L.) (Bivalvia, Pteriidae). J. Shellfish Res. 12(2), 223-228.

Taylor, J., Rose, R.A., Southgate, P.C., 1997. Fouling animals and their effect on the growth of silverlip pearl oysters, Pinctada maxima (Jameson) in suspended culture. Aquaculture 153, 31-40.

Urban, H., 2000. Culture potential of the pearl oyster (Pinctada imbricata) from the Caribbean.: II. Spat collection, and growth and mortality in culture systems. Aquaculture. 189, 375-388.

Wada, K.T., Komaru, A., 1996. Color and weight of pearls produced by grafting the mantle tissue from a selected population for white shell color of the Japanese pearl oyster Pinctada fucata martensii (Dunker). Aquaculture 142, 25-32.

Welschmeyer, N., 1994. Fluorometric analysis of chlorophyll a in the presence of chlorophyll b and pheopigments. Limnol. Oceanogr. 39, 1985-1992.

Yukihira, H., Lucas, J., Klumpp, D., 2000. Comparative effects of temperature on suspension feeding and energy budgets of the pearl oysters Pinctada margaritifera and P. maxima. Mar. Ecol. Prog. Ser. 195, 179-188. 


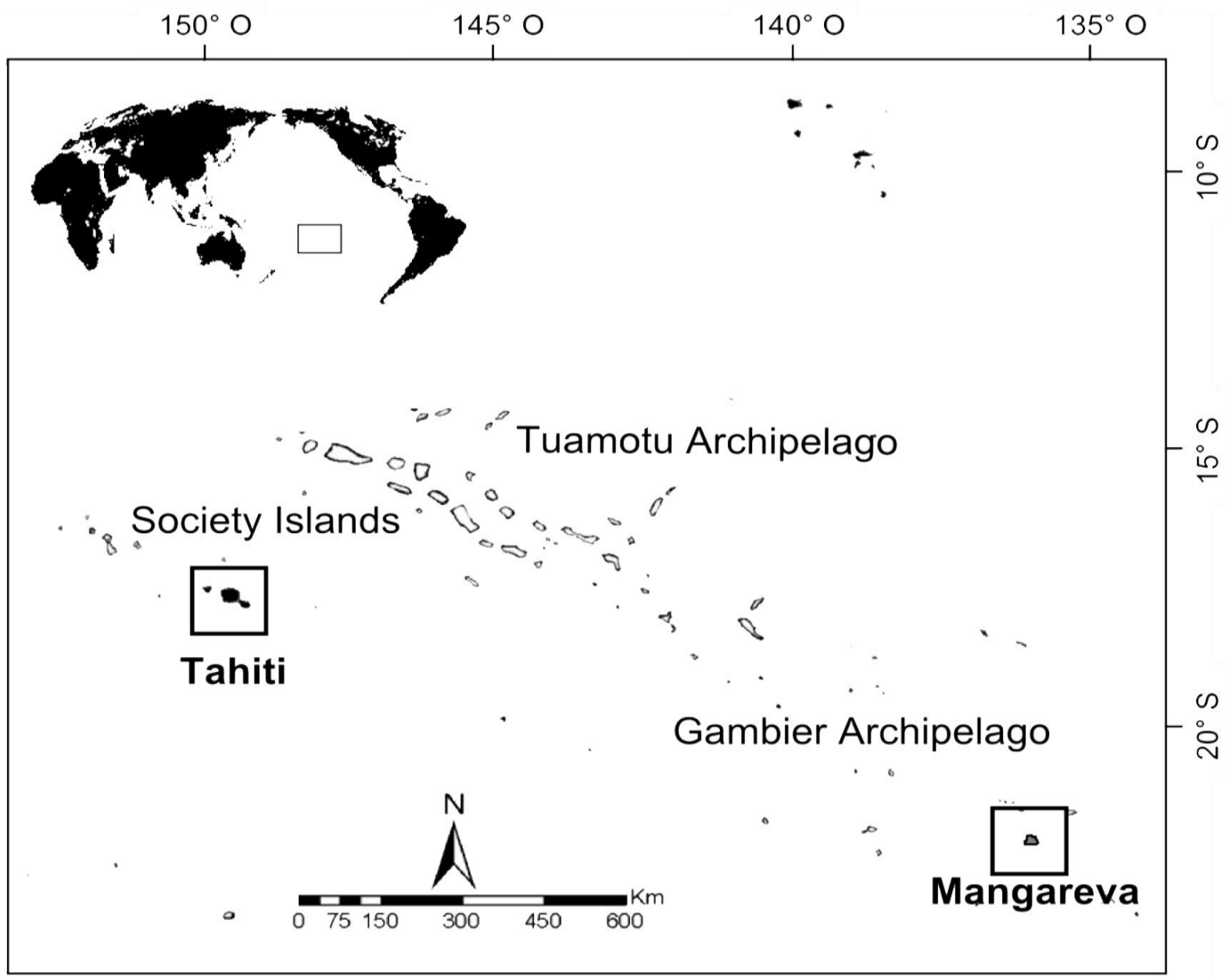

Figure 1 

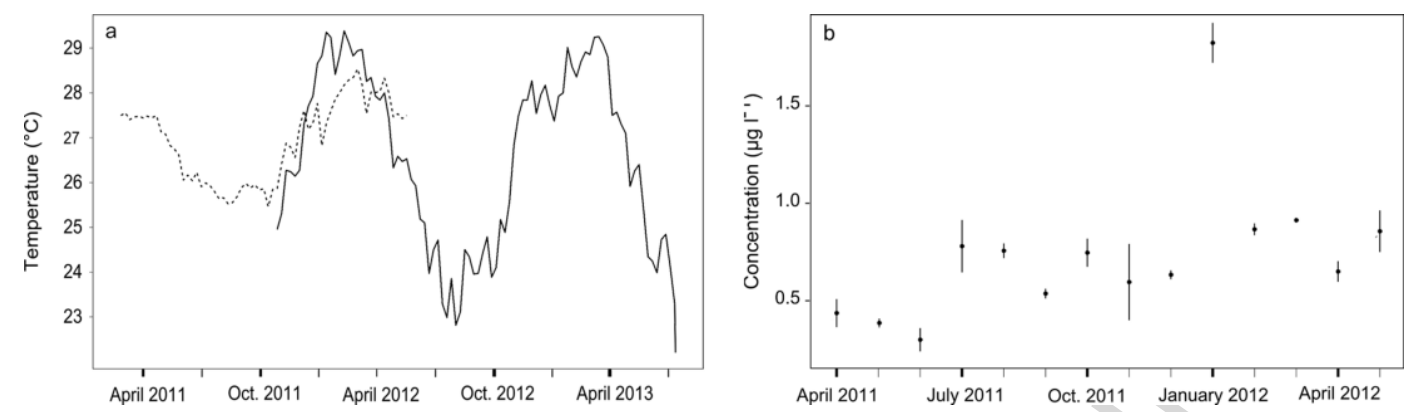

Figure 2 

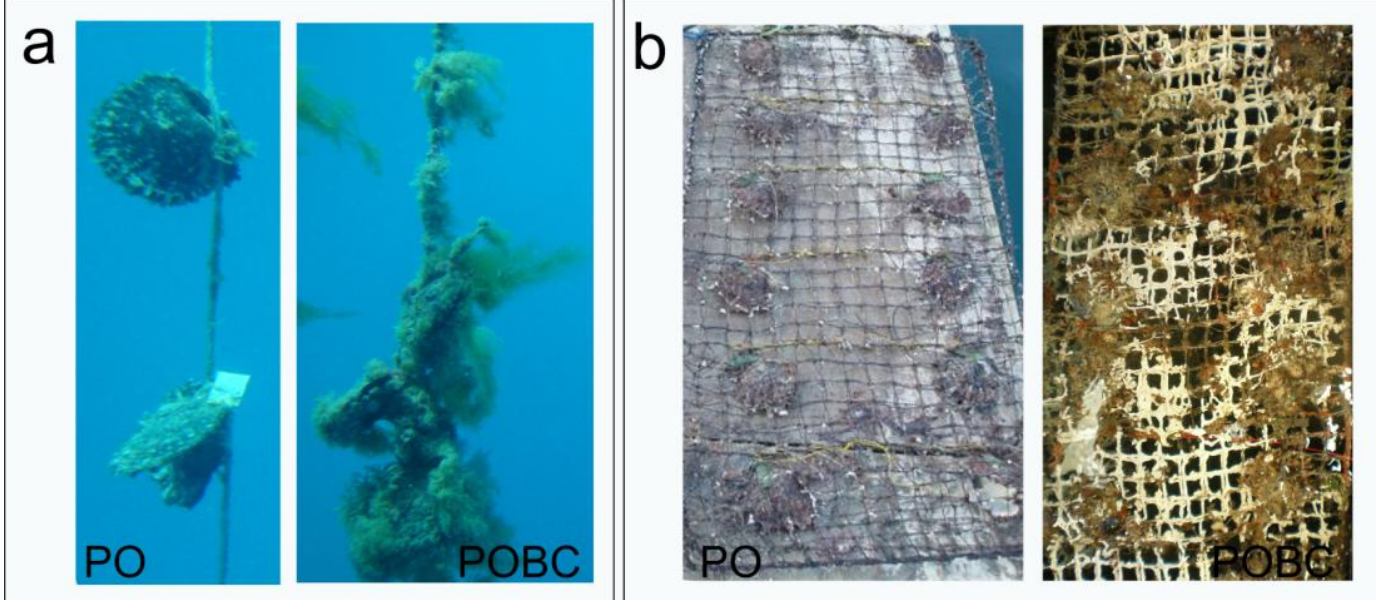

Figure 3 


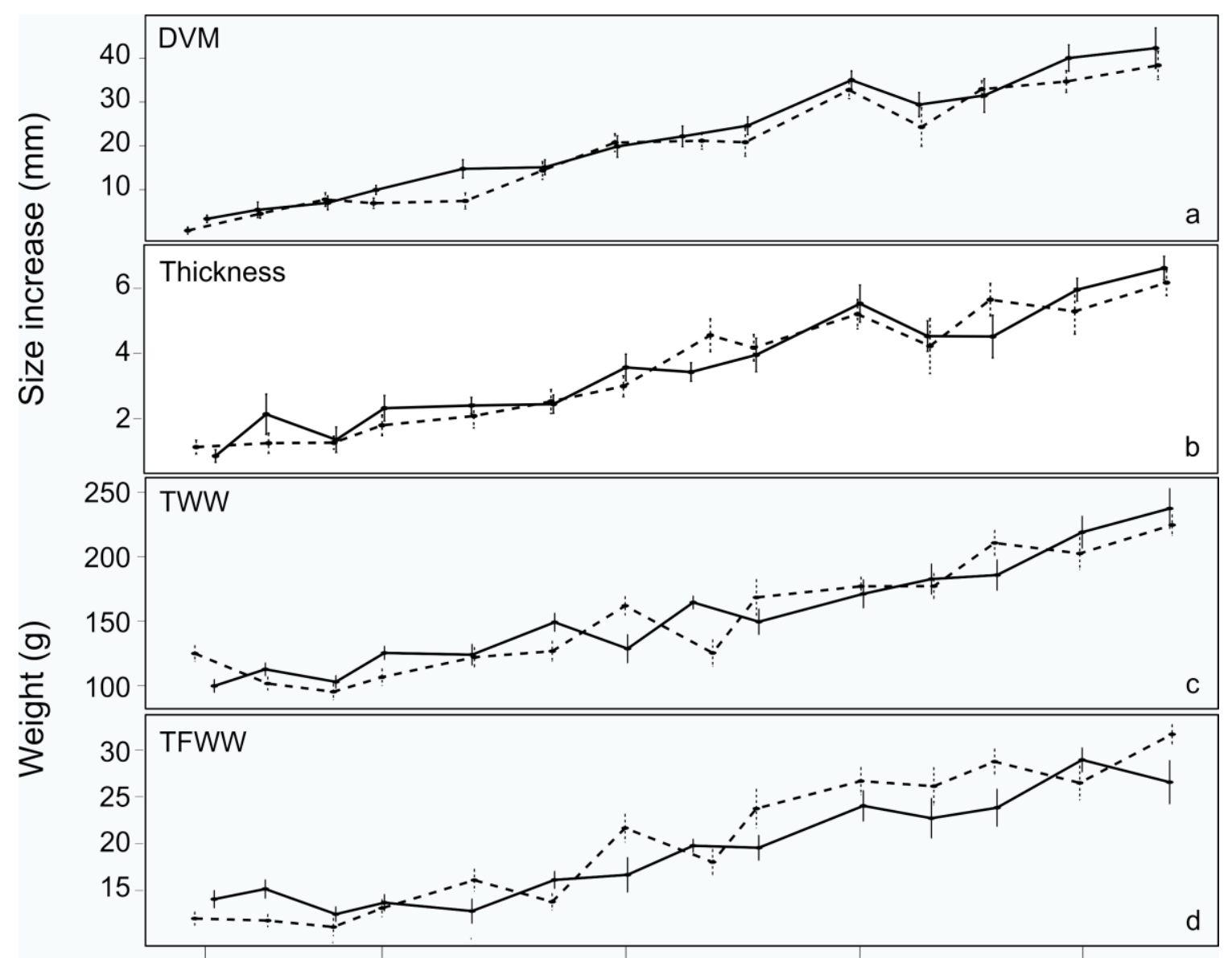

April 2011 July 2011 October 2011 January 2012 April 2012

Figure 4 


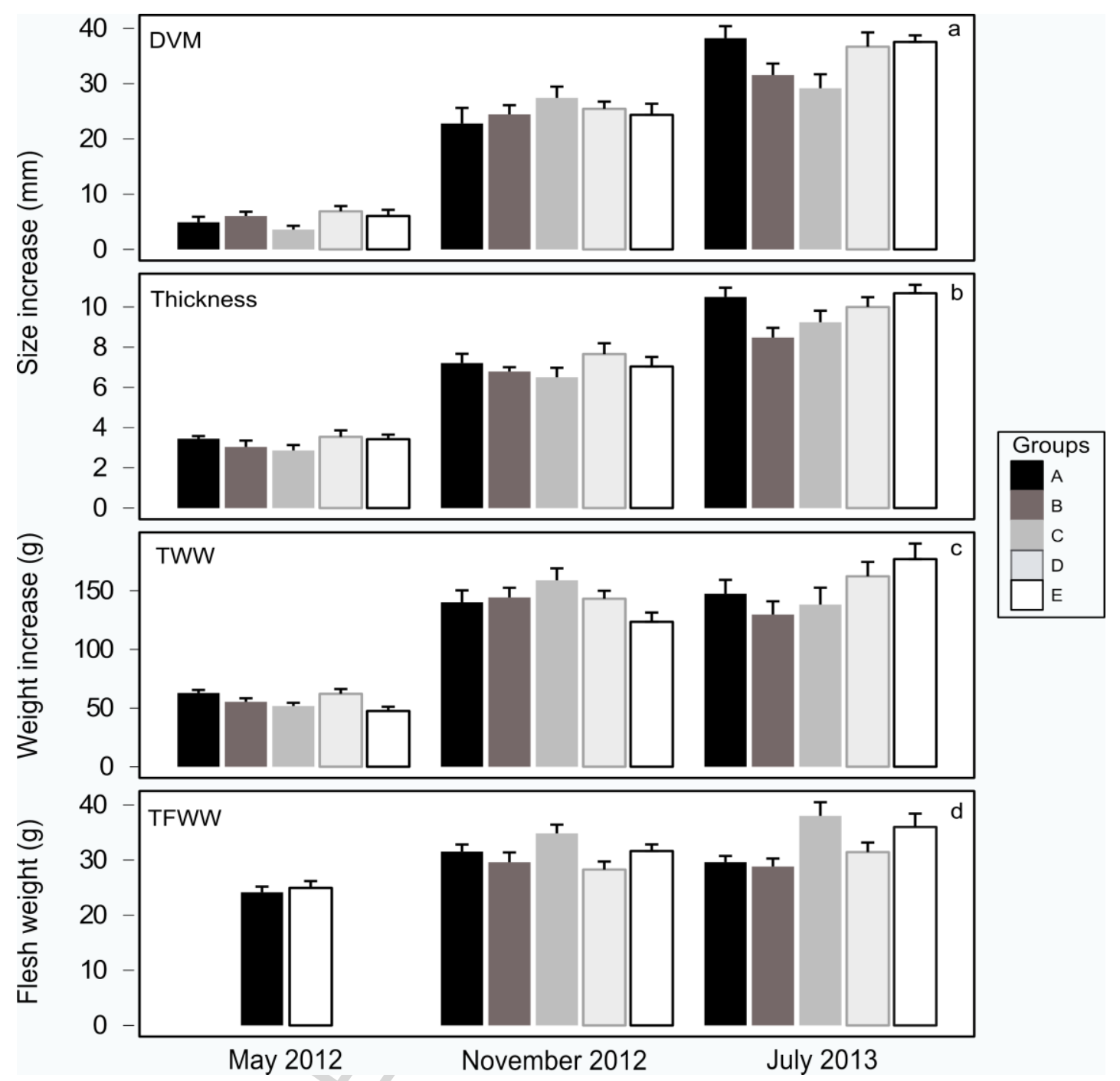

Figure 5 


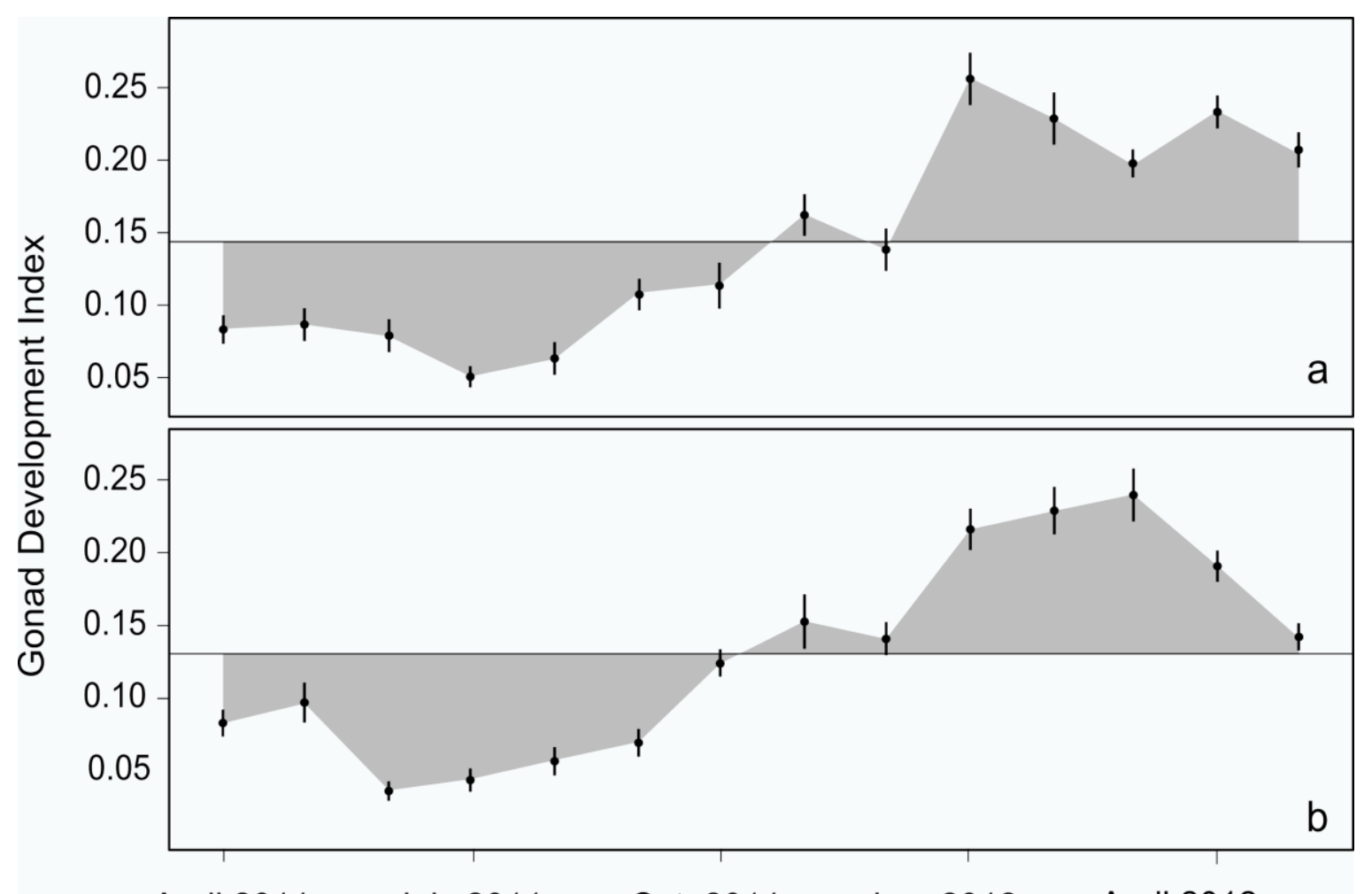

$\begin{array}{lllll}\text { April } 2011 & \text { July } 2011 & \text { Oct. } 2011 \quad \text { Jan. } 2012 \quad \text { April } 2012\end{array}$

Figure 6 

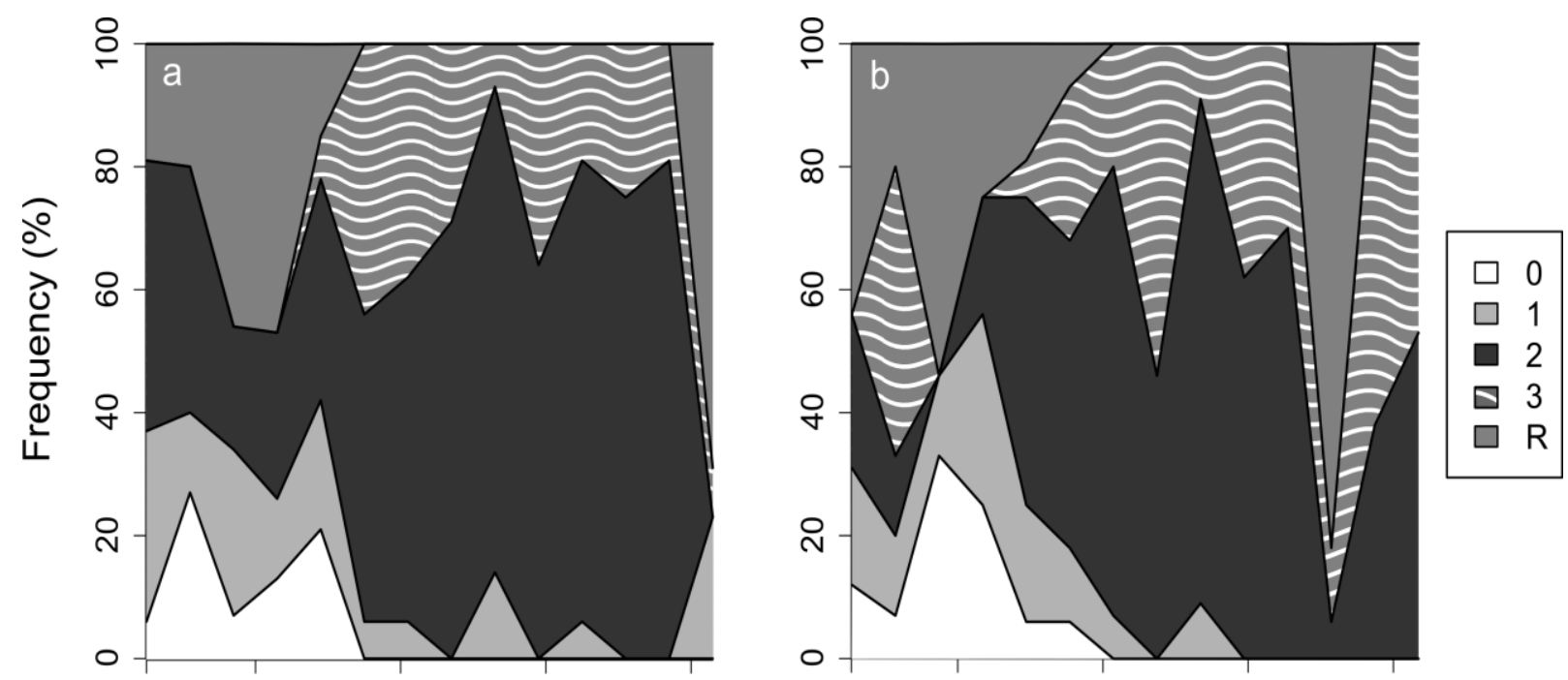

April 2011 July 2011 Oct. 2011 Jan. 2012 April 2012 April 2011 July 2011 Oct. 2011 Jan. 2012 April 2012

\section{Figure 7}




\section{Highlights}

- Effect of biofouling on growth and reproduction of pearl oysters (Pinctada margaritifera) was studied during 2 years

- Results indicated no detrimental effect of biofouling on pearl oysters survival, growth and reproduction

- The necessity of biofouling removal is questioned 